JEL L110

POPKO O.V

Candidate of Economics, Associate Professor

National University of Water and Environmental Engineering

National Academy Of Sciences Of Ukraine

O.Novaka, 75, m. Rivne, Ukraina, 33000

E-mail: o.v.popko@nuwm.edu.ua

ORCID 0000-0003-3356-6070

\title{
INDUSTRY OF RIVNE REGION: CURRENT STATE AND STRATEGIC TARGETS OF DEVELOPMENT
}

Topicality. Increasing attention to the development of industry and industrial policy is one of the main tendencies in the development of the modern world global economy. Wide recognition of the important role of industry in solving current problems has been reflected in new challenges for rapid development of the domestic industry. It is a generator of scientific and technological progress and innovation and an important factor in the competitiveness of national economies and it serves as a driver for economic growth.

Purpose and tasks. The purpose of the article is to identify the situation, problems and prospects of industry development in the Rivne region.

Results. It is established the leading role in the economy of Rivne Oblast is famous for industry and agriculture. It was revealed the leading industries of the Rivne region including production and supply of electricity and gas; Chemical Industry; manufacture of building materials and glassware; Food Industry; manufacture of wood products; engineering. The results of the research on the development of industry in the Rivne region, problems and tasks of its development, SWOT-analysis of the strengths and weaknesses of industry in the Rivne region, opportunities and threats of its development are presented. The primary directions of industry development in the Rivne region have been formed. In particular, modernization of production; introduction of energy-saving technologies; promotion of production of industrial products, competitive in the domestic and foreign markets; an increase in the total volume of foreign direct investment attracted to the regional economy; establishing cooperation with international companies; regulation of the legislative framework on consumer rights protection, advertising, unfair competition, registration of patents and inventions, registration and protection of trademark rights for goods and services.

Conclusions. The following problems of the regional industry must be considered and urgently addressed: moral and physical depreciation of fixed assets, high dependence on world market conditions, high energy intensity of production, production of products with low added value, etc. Instead, key drivers need to become its competitive advantages as a strong raw material base, advantageous geographic position, close proximity to the EU markets, a relatively low share of labor costs in the structure of the cost of industrial products, and a significant unrealized potential of domestic demand for industrial products.

Keywords: industrial policy, industry of Rivne region, SWOT-analysis, strategic directions of industry development.

\section{ПОПКО О.В.}

к.е.н., дои.

Національний університет водного господарства та природокористування

О.Новака, 75, м. Рівне, Украӥна, 33000

E-mail:o.v.popko@nuwm.edu.ua

ORCID: 0000-0003-3356-6070.

\section{ПРОМИСЛОВІСТЬ РІВНЕНСЬКОЇ ОБЛАСТІ: СУЧАСНИЙ СТАН ТА СТРАТЕГІЧНІ ЗАВДАННЯ РОЗВИТКУ}

Актуальність. Посилення уваги до розвитку промисловості та промислової політики є однією з основних тенденцій розвитку сучасного світового господарства. Широке визнання важливої ролі промисловості у 
виріменні актуальних проблем сучасності знайтло відображення в нових завданнях із прискореного розвитку вітчизняної індустрії, що є генератором науково-технічного прогресу й інновацій, важливим фактором конкурентоспроможності національних економік, виступає драйвером економічного зростання.

Мета та завдання. Метою статті є ідентифікація стану, проблем та перспектив розвитку промислових підприємств Рівненської області. В даному дослідженні пропонується провести комплексний аналіз стану, проблем та перспектив розвитку промисловості Рівненської області. Планується виявлення актуальних проблем та перспективних завдань розвитку Рівненської області, проведення SWOT-аналізу сильних та слабких сторін промисловості Рівненщини, можливостей і загроз ї̈ розвитку.

Результати. Встановлено: провідне місце в економіці Рівненської області займають промисловість та сільське господарство. Виявлено: до провідних галузей промисловості Рівненськой області відноситься: виробництво та постачання електроенергіі та газу; хімічна промисловість; виробниитво будматеріалів $i$ скловиробів; харчова промисловість; виготовлення виробів з деревини; машинобудування. Приведено результати, здійсненого на основі досліджень стану розвитку промисловості Рівненської області, проблем та завдань ї̈ розвитку, SWOT-аналізу сильних та слабких сторін промисловості Рівненщини, можливостей $і$ загроз ї̈ розвитку. Сформовано пріоритетні напрямки розвитку промисловості Рівненщини, зокрема: модернізація виробнищтва; запровадження енергозберігаючих технологій; сприяння випуску промислової продукції, конкурентоспроможної на внутрішньому та зовнішньому ринках; збільшення загального обсягу прямих іноземних інвестицій, залучених в економіку області; налагодження співпрачі з міжнародними компаніями; врегулювання законодавчої бази з питань захисту прав споживачів, реклами, недоброякісної конкурениії, реєстрації патентів та винаходів, реєстрації та охорони прав на знаки для товарів та послуг.

Висновки. Обов'язковими до розгляду й негайного вирімення повинні стати такі проблеми регіональної промисловості: моральне й фізичне зношення основних фондів, висока залежність від кон'юнктури на світових ринках, висока енергоємність виробничтва, виробництво продукиії з низькою додатковою вартістю та ін. Натомість, ключовими драйверами повинні стати такі ї̈ конкурентні переваги як потужна сировинна база, вигідне географічне положення, знаходження у безпосередній близькості до ринків СС, відносно низька питома вага витрат на оплату праці в структурі собівартості промислової продукції, суттєвий нереалізований потенціал внутрішнього попиту на продукцію промисловості.

Ключові слова: промислова політика, промисловість Рівненської області, SWOT-аналіз, стратегічні напрямки розвитку промисловості.

Problem statement and its connection with important scientific and practical tasks. Increasing attention to the development of industry and industrial policy is one of the main trends in the development of the modern world economy. Widespread recognition of the important role of industry in solving topical problems of the present has been reflected in the new tasks of accelerated development of the domestic industry, which is a generator of scientific and technological progress and innovation, an important factor of competitiveness of national economies, acts as a driver of economic growth. The global financial and economic crisis and the subsequent recession have clearly demonstrated that those countries that have a developed modern industry can successfully overcome the challenges and get stronger out of them $[12,13]$. Ukraine also needs to intensify these industry benefits, based on an analysis of the current situation in Ukraine and abroad.

Analysis of recent publications on the problem. Aspects of the development of industrial enterprises of Ukraine are considered in the works of O.I. Amoshi, V.P. Vishnevsky, L.O. Zbarazskaya, E.V. Kricavsky, M.V.Malchik, V.P. Pylypchuka, MA Oklander, N.I. Chukraj and others.

Allocation of previously unsolved parts of the general problem. Scientific achievements of scientists have a great theoretical and applied value. However, further research needs actual problems, perspectives and strategic directions of development of domestic industrial enterprises at the level of certain regions of Ukraine, including Rivne.

Formulation of research objectives (problem statement). This study proposes to conduct a comprehensive analysis of the state, problems and prospects of industry development in Rivne region. It is planned to identify the actual problems and perspective tasks of development of Rivne region, conduct SWOTanalysis of the strengths and weaknesses of industry in the Rivne region, opportunities and threats to its development. 
Outline of the main results and their justification. Rivne region has a favorable and geographical location with significant transit potential. The transport corridors cross the territory of the region, including: Crete Transport Corridor No. 3 (Krakivets - Lviv - Rivne - Zhytomyr - Kiev); Crete Transport Corridor No. 5 (Kosini - Chop - Stryi - Lviv - Rivne - Sarny - Minsk); Europe - Asia (Krakivets - Lviv - Rivne - Zhytomyr Kyiv - Poltava - Kharkiv - Debaltsevo - Izvarin); Baltic Sea - Black Sea (Yagodin - Kovel - Lutsk - Ternopil Khmelnytsky - Vinnitsa - Uman - Black Sea ports).

Industry and agriculture occupy the leading place in the region's economy. Rivne region has a significant production potential and developed technical base. In the industrial complex of the region there are 368 large and medium-sized industrial enterprises of various forms of ownership, as well as more than 1,5 thousand small industrial enterprises. Industrial enterprises are mainly located in the largest settlements and cities of Rivne, Kuznetsovsk, Kostopil, Sarny, Zdolbuniv and urban areas. Rokite at the same time, most enterprises extracting industry and the production of construction materials, glassware are formed directly near mineral deposits. These branches are the most investment attractive and provide a significant share of revenues to budgets of all levels [15, p. 704].

Enterprises of the industrial complex of the region are provided with production of $19,5 \%$ of electric power by Ukrainian nuclear power plants, $65 \%$ of the national volume of high-quality plywood, $24,7 \%$ of nonwovens, $21,6 \%$ of particle board, $9,1 \%$ of cement, about $9 \%$ mineral fertilizers. Three glass factories of the region, radically modernized during the years of Ukraine's independence, are one of the largest and most modern in Ukraine. The only match-making factory in the country is the [6].

The dynamics of volumes of sold products (goods, services) in Rivne region in 2013-2017 is presented in Fig. 1. Thus, the volume of sales in 2017 amounted to UAH 31044,3 million and increased in comparison with the volume of 2013 by 2,3 times, and compared with 2016 - by $17,9 \%$.

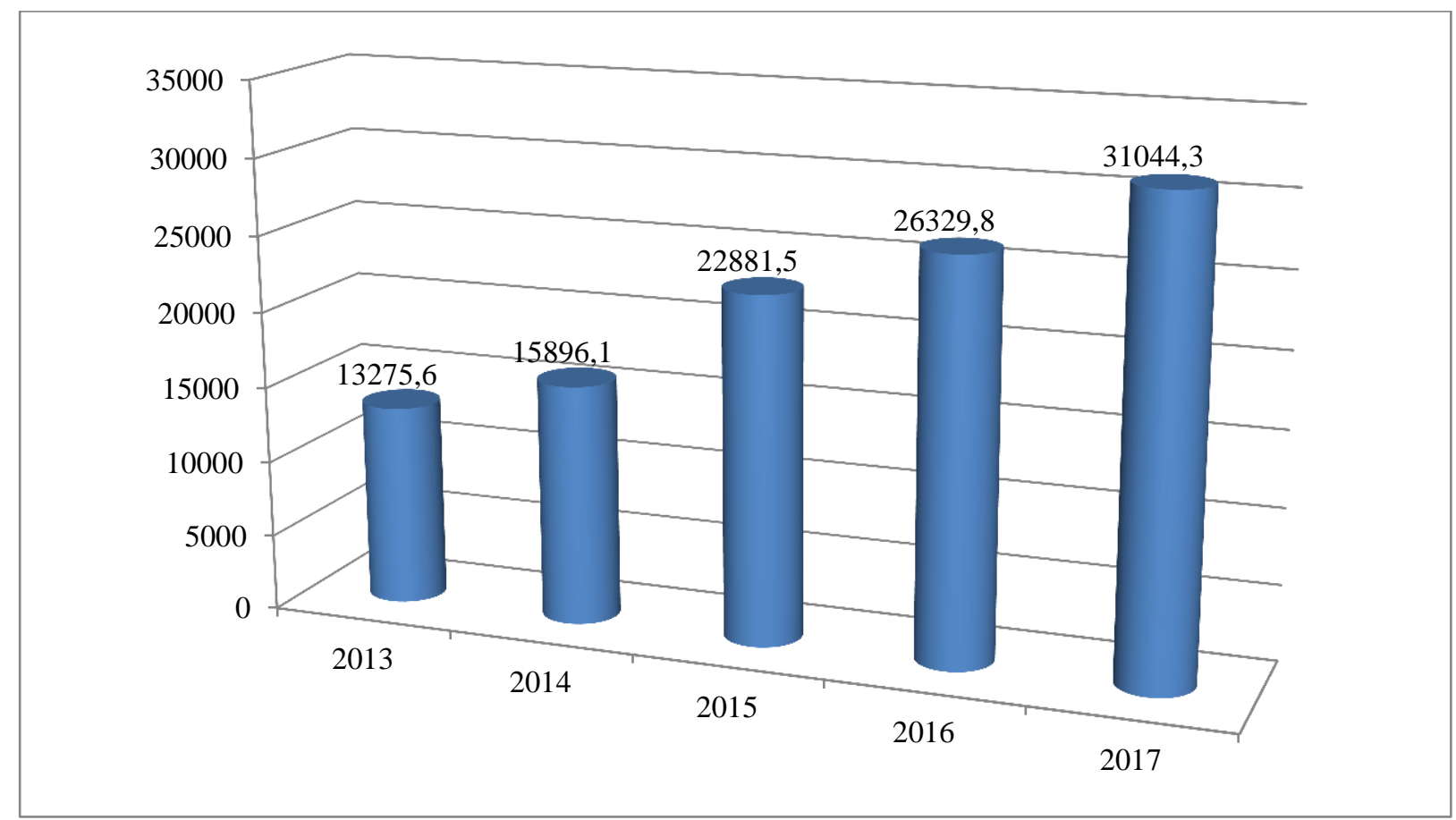

Fig.1. Dynamics of volumes of sold products (goods, services) in the Rivne region in 2013-2017, mln.UAH.

Source: developed by the author on the basis of $[1,2]$

The dynamics of indices of industrial products in Rivne oblast in 2013-2017 (deployed by months) is shown in Fig.2

Economic analysis of growth rates of indices of industrial production for 2013-2017 allowed to reveal the following: in August-December 2017 indices of industrial production exceed the corresponding values for 2013- 
2016. In general, in 2017 index of industrial production compared to the previous 2016 was $109,0 \%$ and reached the maximum value in the last five years.

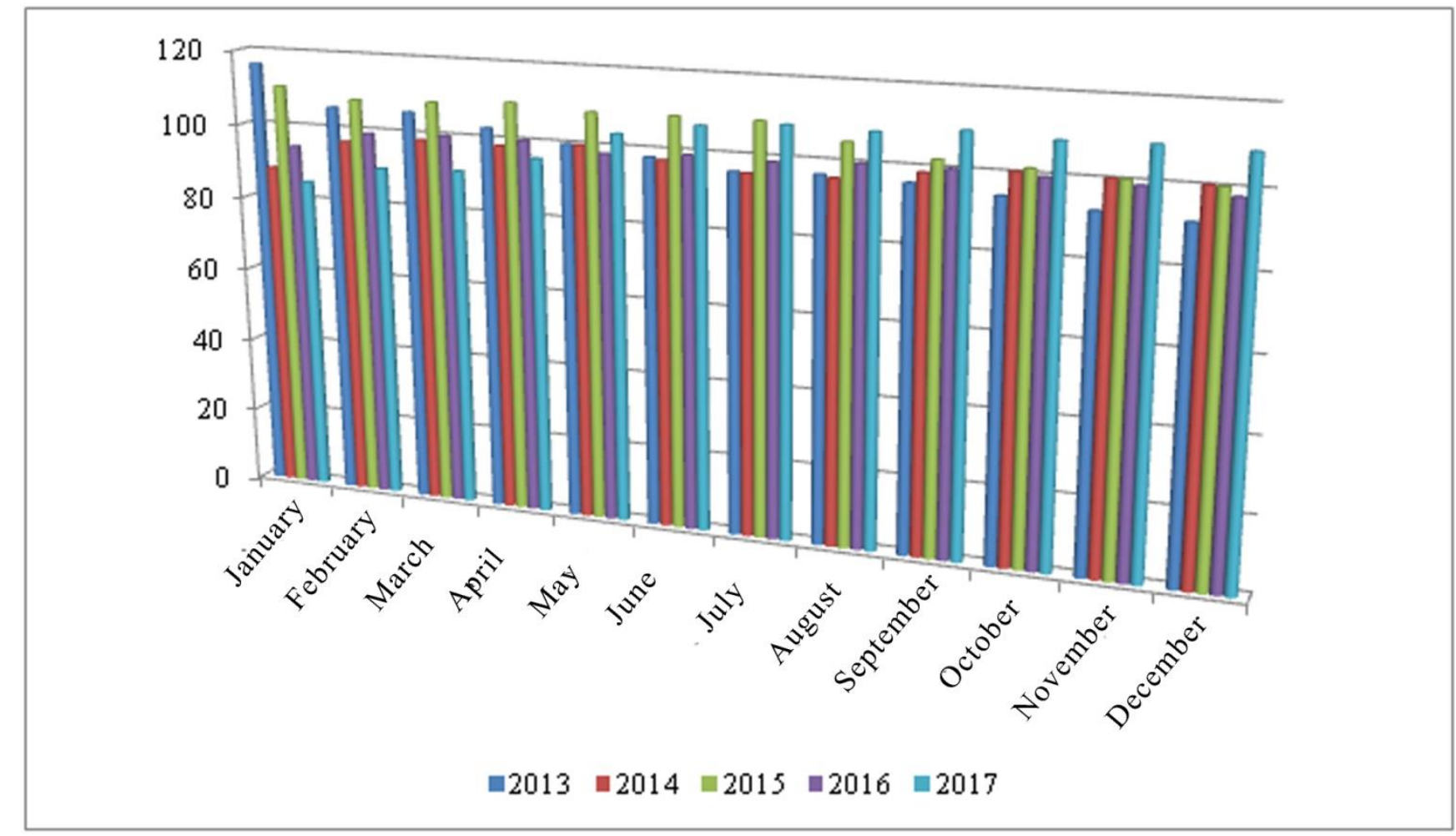

Fig.2. Indices of industrial production in Rivne region in 2013-2017 (in\% to the corresponding period of the previous year)

Source: developed by the author on the basis of $[1,2]$

The leading industries in the Rivne region include: production and supply of electricity and gas; chemical industry; manufacture of building materials and glassware; food industry; manufacture of wood products; machine building (Fig. 3).

Apparently, the lion's share $(39,3 \%)$ in the structure of volumes of sold products in the Rivne region, according to 2017, is textile production, clothing and leather production. The second place is the production of food products, beverages and tobacco products - with a share of $15,9 \%$, and the third place - with a share of $14,4 \%$ - is the production of rubber and plastic products and other non-metallic mineral products.

The analysis of volumes of sold industrial products in Rivne oblast for 2013-2017 (Table 1) made it possible to formulate the following conclusions. In the mining industry and the development of quarries in 2017. compared to 2013 production increased by $43,6 \%$, as compared to 2016 - by $28,0 \%$.

In general, the processing industry has grown substantially over the last five years. Thus, enterprises producing food and beverages in 2017 against 2013 volume of issue increased 2,16 times, including in the processing and canning of fruits and vegetables - by $58,6 \%$, in the production of flour and cereal industry, starch and starch products - by $8 \%$, dairy products - by 4,3 times, bread, bakery and flour products - by $4 \%$ At the same time, volumes in the production of meat and meat products ( 2 times), soft drinks (1,5 times) increased.

Analysis of sales volumes in kind allowed to reveal: in 2017 compared to 2016 the production of flour increased by 7975 tons, the milk of liquid processed - by 5633 tons, yoghurts, other fermented or soured milk and cream - by 1507 tons, natural canned vegetables - by 758 tons, butter butter - by 242 tons, cheeses of whey and melted - by 213 tons, fresh pig meat - by 207 tons, sweet biscuits and waffles - by 92 tons, sausage products - by 84 tons, non-alcoholic beverages - by 73,1 thousand dollars. 


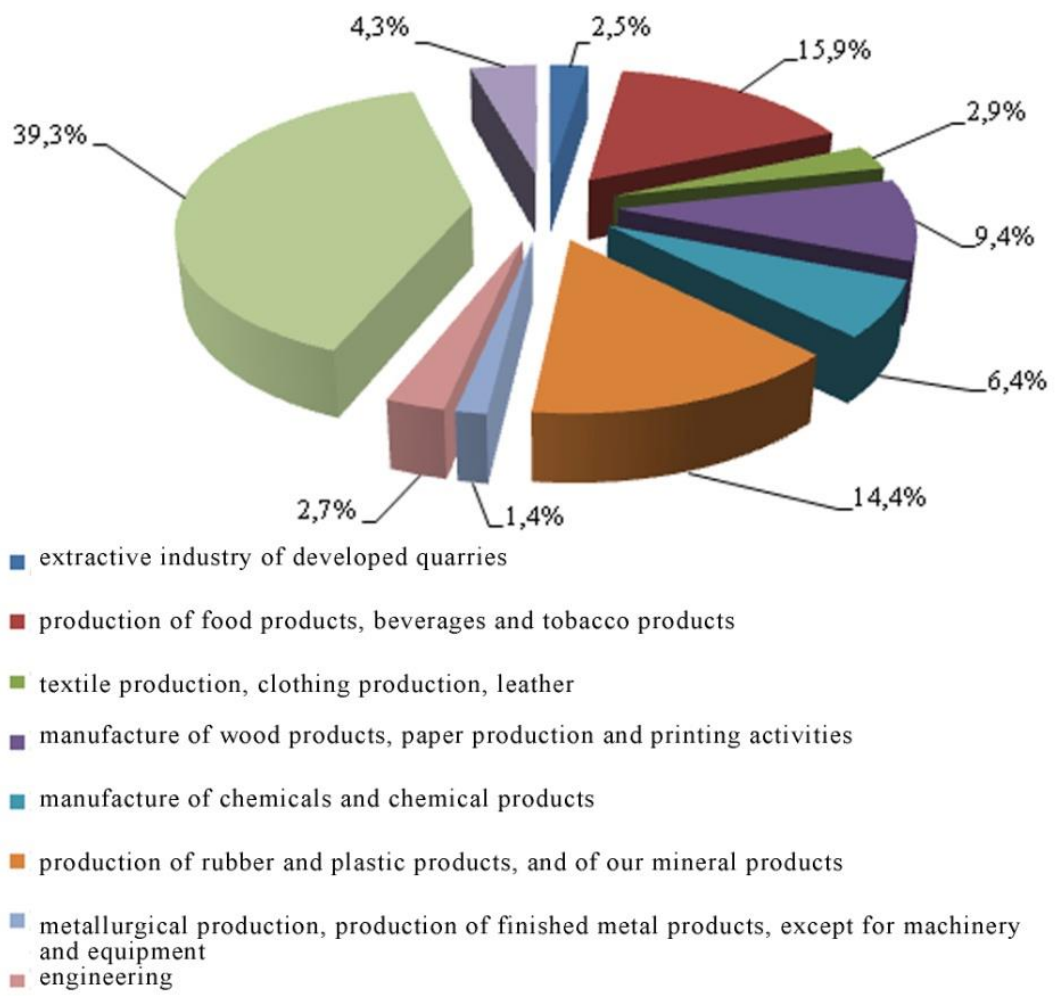

Fig.3. Structure of volumes of sold industrial products in Rivne region by main types of activities in 2017

Source: developed by the author on the basis of $[1,2]$

Table 1

Data on volumes and structure of sold products by main types of industrial activity in Rivne oblast for 2013-2017.

\begin{tabular}{|l|l|l|l|l|l|}
\hline \multicolumn{1}{|c|}{ Types of industrial activity } & \multicolumn{1}{|c|}{2013} & 2014 & 2015 & 2016 & 2017 \\
\hline 1 & 2 & 3 & 4 & 5 & 6 \\
\hline Mining and quarrying & 535571,1 & 575798,2 & 460414,0 & 512050,3 & 768955,1 \\
\hline $\begin{array}{l}\text { Manufacture of food products, } \\
\text { drinks and tobacco products }\end{array}$ & 2283686,5 & 2166996,8 & 3301104,7 & 4100384,7 & 4932536,5 \\
\hline $\begin{array}{l}\text { Textile production, production } \\
\text { of clothes, leather }\end{array}$ & 180619,7 & 229874,7 & 406708,7 & 547862,3 & 908066,3 \\
\hline $\begin{array}{l}\text { Manufacture of wood products, } \\
\text { paper production and printing } \\
\text { activities }\end{array}$ & 1095367,3 & 1427838,1 & 1910269,4 & 2424437,3 & 2908113,2 \\
\hline $\begin{array}{l}\text { Production of coke and refined } \\
\text { products. }\end{array}$ & $\ldots$ & $\ldots$ & $\ldots$ & $\ldots$ & $\ldots$ \\
\hline
\end{tabular}


Continuation of Table 1

\begin{tabular}{|l|l|l|l|l|l|}
\hline & \multicolumn{1}{|c|}{2} & \multicolumn{1}{|c|}{3} & \multicolumn{1}{|c|}{5} & \multicolumn{1}{|c|}{} \\
\hline $\begin{array}{l}\text { Production of chemicals and } \\
\text { chemical products }\end{array}$ & 1922331,2 & 2440670,4 & 3599893,8 & 2917273,0 & 1997007,6 \\
\hline $\begin{array}{l}\text { Production of the main } \\
\text { pharmacist. products and } \\
\text { pharmaceuticals }\end{array}$ & $\ldots$ & $\ldots$ & $\ldots$ & $\ldots$ & $\ldots$ \\
\hline $\begin{array}{l}\text { Manufacture of rubber and } \\
\text { plastic products, other non- } \\
\text { metallic mineral products }\end{array}$ & 1725839,2 & 2082643,8 & 2958163,6 & 3541858,0 & 4461902,5 \\
\hline $\begin{array}{l}\text { Metallurgical production, } \\
\text { production of finished metal } \\
\text { products, except machinery and } \\
\text { equipment }\end{array}$ & 278110,6 & 293482,6 & 431604,0 & 291669,8 & 446011,7 \\
\hline Engineering and supply of & 4469963,9 & 5731020,7 & 8257052,4 & 10223976,9 & 12190927,0 \\
\hline $\begin{array}{l}\text { Production and } \\
\text { electricity and gas }\end{array}$ & & & & & \\
\hline $\begin{array}{l}\text { Water supply; sewage, waste } \\
\text { management }\end{array}$ & 49443,6 & 62440,9 & 203876,6 & 226378,7 & 261989,8 \\
\hline Total: & 13275575,4 & 15896145,0 & 22881461,2 & 26329776,6 & 31044262,1 \\
\hline
\end{tabular}

Notes: " The data on the section is not made public in order to ensure compliance with the requirements of the Law on State Statistics on the confidentiality of statistical information

At the same time, the output of unrefined oil was 2820 tons, fresh meat of fresh beef - 1876 tons, sugar confectionery products not containing cocoa - 1228 tons, jam, fruit jelly, mashed potatoes and pastas - 796 tons, sauces and products for making sauces; seasonings and spices of mixed others - by 150 tons. In general, in the processing industry for the last five years the volume of food production has increased significantly. Thus, enterprises producing food products and beverages in 2017 compared to 2013, the volume of production has been increased by 2,16 times, including in the processing and canning of fruits and vegetables - by $58,6 \%$, in the production of flour and cereal industry, starch and starch products - by $8 \%$, dairy products - by 4,3 times, bread, bakery and flour products - by $4 \%$ At the same time, meat and meat products (by 2 times) and non-alcoholic beverages (1,5 times) grew.

Analysis of volumes of sales in kind allowed to reveal: in 2017, compared to 2016, the production of flour increased by 7975 tons, milk of processed liquid - by 5633 tons, yoghurts, other fermented or sour milk and cream - by 1507 tons, natural canned vegetables - by 758 tons, cream butter - by 242 tons, cheeses of whey and melted - by 213 tons, fresh pig meat - by 207 tons, sweet biscuits and waffles - by 92 tons, sausage products - by 84 tons, soft drinks - by 73,1 thsd. At the same time, the output of unrefined oil was 2820 tons, fresh meat of fresh beef - 1876 tons, sugar confectionery products not containing cocoa - 1228 tons, jam, fruit jelly, mashed potatoes and pastas - 796 tons, sauces and products for making sauces; seasonings and spices of mixed others by $150 \mathrm{t}$. In 2017 there was an increase in the production of bread and baked goods of short-term storage - by 48 tones of chocolate and ready-made food products containing cacao - by $40 \mathrm{t}$, natural gas mined gas - by 36,7 thsd.

In the textile industry, the production of clothing, leather, leather goods and other materials in 2017compared with 2013, the growth of products in 5,02 times (compared with $2016-65,7 \%$ ). In the manufacture of wood products, paper and printing activities in 2017 compared to 2013, output increased 2,65 times (compared with 2016, output in 2017 increased by 19,9\%). In the production of chemicals and chemical products, the growth of volumes compared to 2013 amounted to $38,85 \%$. Instead, compared to 2016, in 2017 there was a decline in production by $31,55 \%$. In the enterprises for the production of rubber and plastic products, other non-metallic mineral products output volumes against 2013 increased by 2,6 times (compared to 
2016, output in 2017 increased by 26\%). In metallurgical industry, production of finished metal products, except for machinery and equipment, in 2017, compared to 2013, the index of industrial production amounted to $160,4 \%$ (compared with $2016-152,9 \%$ ), in machinery other than repair and installation machinery and equipment - 169,9\% (compared with 2016 - 129,4\%). In the supply of electricity, gas, steam and air conditioning compared to 2013. the volume of production has been increased by 2,7 times (compared with 2016 - by 19,2\%).

The main program documents defining the priorities, tasks and activities of the executive authorities of the region for the development of the economic complex and social sphere are: Strategy for the development of the Rivne region for the period up to 2020 (the order of the head of the regional state administration dated November 28, 2014 No. 612, the decision of the regional council of 18.12. 2014 №1374) [15], Plan for 2015 2020 on implementation of the Strategy for the development of Rivne Oblast (Order of the Head of the Regional State Administration dated May 27, 2015, No. 273, decision of the Regional Council dated June 12, 2015, No. 1471).

According to the program documents, the priority strategic goals of industry development in Rivne region by 2020 are:

$>$ modernization of production;

$>$ introduction of energy-saving technologies;

$>$ promoting the release of industrial products competitive in the domestic and foreign markets;

$>$ an increase in the total volume of foreign direct investment attracted to the regional economy;

$>$ establishing cooperation with international companies;

$>$ regulation of the legislative framework on consumer rights protection, advertising, poor competition, registration of patents and inventions, registration and protection of trademark rights for goods and services.

At the same time, today the industrial enterprises of the region carry out appropriate work on improving the quality of products, developing, implementing and certifying the quality management system [3, 11, 14]. In particular, JSC "Rodina" implemented and constantly improves the integrated system of quality and food safety management to meet the requirements of DSTU ISO 9001: 2009 and DSTU ISO 2000: 2007. The internal audits carried out in accordance with the HACCP plan analyze the biological, physical and chemical risks that may affect the quality and safety of food products. In addition, the company operates a measuring laboratory, which controls the quality of incoming raw materials and finished products.

The PJSC "Rokitnivsky Glass Factory" introduced and operates a quality management system ISO 9001: 2008. In November 2016, the company successfully passed the certification in accordance with the requirements of the international standard FSSC 22000: 2015 and received a certificate confirming the operation of the system at the enterprise issued by the certification body TUV Thuringene.V.

At Open Company "Klesiv quarry of non-metallic minerals" Technobud "- cubic granite gravel is certificated not only according to domestic standards, but also according to international standards, in particular, Poland, Belarus. One of the achievements is introduction of the company and voluntary certification of quality management systems and environmental management in accordance with the requirements of international standards. The products undergo quality control at all stages of production, starting with the quality of raw materials, the production process and ending with the delivery of products to the customer.

The High Voltage Union - RZVA - the products are manufactured under controlled conditions established by the quality management system operating in accordance with the requirements of ISO 9001. In addition, two test samples of the upgraded switch VR6V with a rated voltage of 1600A and 3150A were successfully tested at the international testing center for compliance with IEC62271-100 2012 in Romania - ICMET CRAIOVA (NATIONAL INSTITUTE FOR RESEARCH-DEVELOPMENT AND TESTING IN ELECTRICAL ENGINEERING - ICMET CRAIOVA).

In December 2017, foreign investors implemented the project "Reconstruction of the sawmill-wood processing industry for the production of lumber in the amount of 300 thousand cub.m / year" and the company "Ukrainian Sawmills" Ltd., which is the producer of quality pine logs using FSC, was put into operation. ${ }^{\text {TM }}$ certified raw materials for ecologically clean and renewable forests of Ukraine. The volume of investments is 25 million euros. The company created 150 new jobs.

In December 2017, at the Morgan Feniche LLC, in order to increase production capacity, a newly built building of the procurement and assembly plant with a total area of $19,000 \mathrm{~m}^{2}$ was put into operation, the estimated cost of construction of which exceeds $94 \mathrm{mln}$. It is planned to create up to 900 new jobs. 
At the LLC "ODEK" Ukraine is in the final stage an investment project to expand the production of plywood with the use of free premises of the workshop of fiberboard, the cost of which reaches 7 million euro. Implementation of this project will allow the output of 105 thousand $\mathrm{m} 3$ plywood per year.

Work continues on the establishment of production of veneered slabs based on MDF, plywood and chipboard, joinery slabs on the "ESCADA-M" Ltd. (Ostrog). It is planned to put into operation the shop number 1 on the lacquer of veneered products, it is planned to create up to 20 jobs.

Taking into account the condition and development prospects of Rivne Oblast, we conducted a marketing SWOT-analysis, the results of which are presented in Fig. 4.

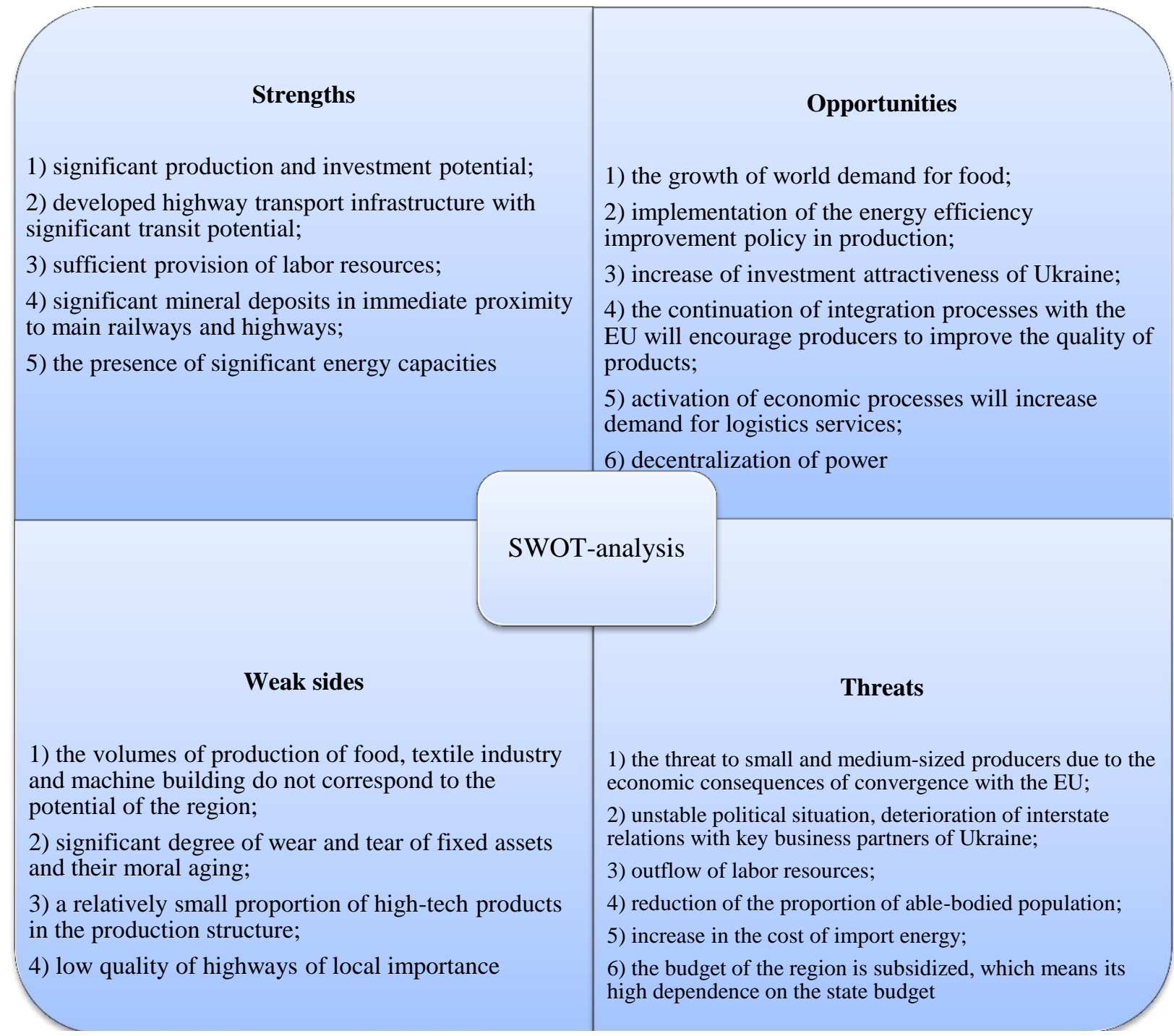

Fig.4. SWOT analysis of industry in Rivne region

Source: developed by the author on the basis of $[3,5,8,9,10,11,14,15]$

Despite the strengths and capabilities of Rivne oblast industrial enterprises, the volumes of food, textile and mechanical engineering production can be restrained as a result of certain threats, including corrupt power and judicial structures, controlling bodies, the complexity of permit-approval procedures, outflow of labor and increase in the cost of imported energy. Instead, the work on expansion of product markets needs to be intensified, especially in the context of the free trade area with EU countries. The growth of investment attractiveness of the Rivne region and the revitalization of investment attraction processes will also contribute to the growth of industrial production and full potential use.

However, the growth of business activity of industrial enterprises of the Rivne region negatively affects the state of the environment. The industrial complex occupies a leading place in terms of the intensity of environmental impact. The main pollutants of atmospheric air in 2017 as in previous years remain the enterprises of the chemical industry (PJSC "Rivneazot"), the production of building materials (Volyn-cement 
branch of PJSC "Dyckerhoff cement Ukraine"), woodworking industry (LLC "Svispan Limited" , LLC "ODEK" Ukraine) and the production of glassware (PrJSC "Consumers-Glass-Zorya").

Communal enterprises that dispose of crude and under-treated waste water (Communal enterprise "Dubno-Vodokanal", Kuznetsovsk municipal communal enterprise of Varash, Ostroh KP "Vodokanal", DKP "Kostopolvodokanal", "Ekoservice" m) are left with water contaminants of the region. Sarny, Communal enterprise "Bereznevodokanal", communal enterprise "Communal" of the city of Radivilov, Orzhiv VVZHKG, "Combine of communal enterprises", Mlyniv village, etc.) [4].

The most polluted industrial emissions are the territory of Rivne, Zdolbuniv, Rivne, Dubensky, Kostopil and Sarnen districts.

Mining industry also negatively affects land resources. During mining, the natural landscapes of the area change, soil-vegetation is disturbed. Sometimes the land reclamation on the site of open-mined mineral deposits, restoration of fertility and national economic value of disturbed lands is not fully implemented.

The chemical and petrochemical industry includes the industrial enterprises of Rivne region: Rivneazot PJSC for the production of mineral fertilizers, "Color Siemens" LLC for the production of paints and varnishes, LLC "Enterprise with foreign investments" Isotherm-S "- for the production of products from the plastics, LLC "Ukrainian match factory" - for the production of explosives and others, etc. Among the main problems of the industry there is a significant accumulation of phosphogypsum at PJSC "Rivneazot".

Today, most of the enterprises of the meat and dairy industry of the Rivne region, having no local processing facilities, dispose of aggressive wastewater on municipal wastewater treatment facilities of settlements. This often leads to crashes in the operation of treatment facilities and the leakage of non-treated wastewater in the water objects of the area.

European standards dictate special requirements for the environmental safety of products, both at the stages of its design, development, production, storage, and on the stage of utilization after use, thereby stimulating the development of the market for eco-innovative innovations. Among the main European standards in the field of ecology: ISO 9000 - international quality management systems and ISO 14000 - environmental management.

According to the State Enterprise «Rivne Regional Center for Standardization, Metrology and Certification» environmental management systems are certified in accordance with DSTU of ISO 14001 series at industrial enterprises: LLC Klesivskyi quarry of non-metallic minerals «Technobud»; "Samgaz" Ltd LLC "Eokorembud LTD".

Quality control systems in accordance with DSTU of the ISO 9001 series are certificated at 26 enterprises of the region, in particular: LLC "Radema"; TDV "Rivneholod"; PJSC "Polissya Khlib"; TzOV VKP "CONTROL SYSTEMS MANAGEMENT"; LLC "Ecoline"; LLC "Klesiv quarry of non-metallic minerals" Technobud "; PJSC "Agroresurs"; PJSC "Rivneshlyakhbud"; SAMGAZ Ltd.; PP "Autotechnology"; PJSC Euroshpon-Smig; Scientific-production enterprise "Mistyme"; "Selyshchansky Granite Quarry" Ltd; LLC "Rivneagrospetsmontazh"; LLC "Eokorembud LTD"; Rivne Center for Hydrometeorology; Technotek LLC; LLC "ECH Technologies"; LLC "Rivne Standard"; "Rich Land" LLC; LLC "Terlich"; LLC "Steel-M"; Technipriv LLC; LLC "High Voltage Union - RZVA"; PE "SDK" Daedal "; LLC "BK DOMINANT" [4].

In order to reduce the technogenic load on the environment and minimize its pollution at the enterprises of the oblast, annual plans for environmental protection measures are developed and approved, namely: for the protection of atmospheric air, for the protection and rational use of water resources, for the protection of land and underground water, waste management and hazardous substances, mineral resources and rational subsoil use.

Conclusions and perspectives of further research. The results of the economic analysis of the state and prospects of industry development in the Rivne region made it possible to formulate the following conclusions. Obligatory for consideration and immediate solution are the following problems of the regional industry: moral and physical depreciation of fixed assets, high dependence on the market conditions on the world markets, high energy intensity of production, production of products with low added value, ensuring food and environmental safety, etc. . Instead, the key drivers should be its competitive advantages as a strong raw material base, advantageous geographical location, close proximity to the EU markets, a relatively low proportion of labor costs in the structure of the cost of industrial products, a significant unrealized potential of domestic demand for industrial products. 


\section{ЛІТЕРАТУРА}

1. Головне управління статистики в Рівненській області [Електронний ресурс]. - Режим доступу: http://www.rv.ukrstat.gov.ua/.

2. Державна служба статистики України. [Електронний ресурс]. - Режим доступу: http://www.ukrstat.gov.ua/ (дата звернення: 14.09.2018).

3. Державна служба України з питань безпечності харчової продукції та захисту прав споживачів [Електронний ресурс]. - Режим доступу: http://www.consumer.gov.ua/.

4. Доповідь про стан навколишнього природного середовища в Рівненській області [Електронний pecypc]. - Режим доступу: http://www.ecorivne.gov.ua/report_about_environment/.

5. Експортна стратегія України. [Електронний ресурс]. - Режим доступу: https://www.kmu.gov.ua/ua/npas/pro-shvalennya-eksportnoyi-strategiyi-ukrayini-dorozhnoyi-kartistrategichnogo-rozvitku-torgivli-na-20172021-roki (дата звернення: 27.12.2017).

6. Кириченко В.В. Промисловість Рівненської області: проблеми і перспективи розвитку / В.В.Кириченко. // Науковий вісник Миколаївського національного університету ім. В.О.Сухомлинсько1го. Миколаїв, 2015. - Вип.5. - С.704-707.

7. Крикавський $€$. Промисловий маркетинг: Підручник. 2-ге вид./ Крикавський $Є .$, Чухрай Н.// Львів: Видавництво НУ «Львівська політехніка», 2005. - 472 с.

8. Маркетингово-логістичні процеси в економіці: теорія та практика: Монографія / Мальчик М.В., Попко О.В.,Гонтаренко Н.А., Толчанова 3.О., Мартинюк О.В., Коваль С.І., та ін.; за редакцією Мальчик М.В. - Рівне : НУВГП, 2015. - 197 с.,

9. Мальчик М.В. Маркетингові дослідження інноваційної діяльності вітчизняних промислових підприємств/ Мальчик М.В., Попко О.В., Толчанова 3.О. // Economic efficiency of business in the conditions of unstable economy: Collective monograph -Aspekt Publishing, Taunton, MA, United States of America, 2015. - p.207-212.

10. Маркетинг: Навчальний посібник / За заг. ред. Мальчик М. В. - Рівне : НУВГП, 2014.- 444 с.

11.Нова промислова політика України [Електронний ресурс]. - Режим доступу: http://informat.com.ua/uk/nova-promislova-politika-ukraini/.

12.Оснач О. Ф. Промисловий маркетинг: підручник / О. Ф. Оснач, В. П. Пилипчук, Л. П. Коваленко. - Київ: Центр учбової літератури, 2009. - 365 с.

13.Промисловість і промислова політика України 2013: актуальні тренди, виклики, можливості: наук.аналітична доповідь / О.І. Амоша, В.П. Вишневський та ін.; за заг. Ред.В.П.Вишневського; НАН України, Інт економіки пром-сті. - Донецьк, 2014. - 200 с.

14.Пропозиції до плану першочергових дій з розвитку промисловості України. [Електронний pecypc]. - Режим доступу: https://www.uifuture.org/publications/news/22080-plan-po-razvitiu-promyslennostiukrainy-doklad-uif-dla-minekonomiki-2017 (дата звернення: 14.10.2018).

15.Стратегія розвитку Рівненської області на період до 2020 року [Електронний ресурс]. - Режим доступу: http://surdp.eu/uploads/files/Rivnenska_RDS_FINAL_UA.pdf. 5.

\section{REFERENCES}

1. Holovne upravlinnia statystyky v Rivnenskii oblasti [The Main Department of Statistics in Rivne Oblast]. Retrieved from http://www.ukrstat.gov.ua/ [in Ukrainian].

2. Derzhavna sluzhba statystyky Ukrainy [The Report on the State of the Environment in the Rivne Region]. Retrieved from http://www.ecorivne.gov.ua/report_about_environment/ [in Ukrainian].

3. Derzhavna sluzhba Ukrainy $\mathrm{z}$ pytan bezpechnosti kharchovoi produktsii ta zakhystu prav spozhyvachiv [Site of The State Service of Ukraine for Food Safety and Consumer Protection]. Retrieved from http://www.consumer.gov.ua [in Ukrainian].

4. Dopovid pro stan navkolyshnoho pryrodnoho seredovyshcha v Rivnenskii oblasti [The Report on the State of the Environment in the Rivne Region]. Retrieved from http://www.ecorivne.gov.ua/report_about_environment/ [in Ukrainian].

5. Eksportna stratehiia Ukrainy [The Export strategy of Ukraine]. Retrieved from https://www.kmu.gov.ua/ua/npas/pro-shvalennya-eksportnoyi-strategiyi-ukrayini-dorozhnoyi-kartistrategichnogo-rozvitku-torgivli-na-20172021-roki [in Ukrainian].

6. Kyrychenko, V.V. (2015). Promyslovist Rivnenskoi oblasti: problemy i perspektyvy rozvytku [Industry of Rivne Oblast: problems and perspectives for development]. Nikolaev: Scientific journal of Nikolaev National 
University named after. V.O. Sukhomlynsky, 5, 704-707. Retrieved from http://global-national.in.ua/archive/52015/144.pdf [in Ukrainian].

7. Krykavskyi, Ye., \& Chukhrai , N. (2005). Promyslovyi marketynh [Industrial Marketing]. Lviv: Publishing house «Lvivska Polytechnika» [in Ukrainian].

8. Marketynhovo-lohistychni protsesy $\mathrm{v}$ ekonomitsi: teoriia ta praktyka: Monohrafiia (2015). [Marketing and Logistics Processes in Economics: Theory and Practice: Monograph]. Rivne: NUVGP. [in Ukrainian].

9. Malchyk, M.V., \& Popko, O.V.,\& Tolchanova, Z.O. (2015). Marketynhovi doslidzhennia innovatsiinoi diialnosti vitchyznianykh promyslovykh pidpryiemstv [Marketing researches of innovation activity of domestic industrial enterprises]. Economic efficiency of business in the conditions of unstable economy: Collective monograph, 207-212. Retrieved from http/ ecofin.at.ua/monografy_01_2015.pdf [in Ukrainian].

10. Marketynh: Navchalnyi posibnyk (2014). [Marketing: Textbook]. Rivne: NUVGP [in Ukrainian].

11. Nova promyslova polityka Ukrainy [New industrial policy of Ukraine]. Retrieved from http://informat.com.ua/uk/nova-promislova-politika-ukraini/ [in Ukrainian].

12. Osnach, O. F. (2009). Promyslovyi marketynh: pidruchnyk [Industrial Marketing: Textbook]. Kyiv: Center for Educational Literature [in Ukrainian].

13.Promyslovist i promyslova polityka Ukrainy 2013: aktualni trendy, vyklyky, mozhlyvosti: nauk.analitychna dopovid (2014). [Industry and Industrial Policy of Ukraine 2013: Current Trends, Challenges, Opportunities: Sciences-Analytical Report]. Donetsk: National Academy of Sciences of Ukraine, Institute of Industrial Economics [in Ukrainian].

14. Propozytsii do planu pershocherhovykh dii z rozvytku promyslovosti Ukrainy [The Proposals to the plan of priority actions for the development of industry in Ukraine]. Retrieved from https://www.uifuture.org/publications/news/22080-plan-po-razvitiu-promyslennosti-ukrainy-doklad-uif-dlaminekonomiki-2017 [in Ukrainian].

15. Stratehiia rozvytku Rivnenskoi oblasti na period do 2020 roku [Strategy of development of Rivne region for the period up to 2020]. Retrieved from http://surdp.eu/uploads/files/Rivnenska_RDS_FINAL_UA.pdf. 5 [in Ukrainian]. 